\title{
The effects of legume seeds on the lactation performance of dairy cows fed grass silage-based diets
}

\author{
Mohammad Ramin ${ }^{1}$, Annika Höjer ${ }^{1,2}$, Mårten Hetta ${ }^{1}$ \\ ${ }^{1}$ Department of Agricultural Research for Northern Sweden, Swedish University of Agricultural Sciences, \\ SE-901 83 Umeå, Sweden \\ ${ }^{2}$ Current: Norrmejerier Ek. Förening, Mejerivägen 2, SE-90622 Umeå, Sweden \\ e-mail: mohammad.ramin@slu.se
}

\begin{abstract}
The aim was to study if locally produced organic legume seeds as protein supplement could improve the performance of dairy cows. The experiment was a cyclic change over design were the control diet consisted of grass silage and barley (60:40) on a dry matter (DM) basis. Barley was replaced with rapeseed expeller (RSE), or isonitrogenous supplements of peas, untreated field beans (UFB), heat-treated FB (TFB) or a lower level of TFB (TFB-low) that provided the same dietary metabolizable protein concentrations as of UFB. None of the legume protein supplementations had effect on DM intake (DMI) neither on energy corrected milk yield compared to control. The RSE treatment increased milk ( 24.8 vs. $23.6 \mathrm{~kg} \mathrm{~d}^{-1}$ ) and protein yield (913 vs. $863 \mathrm{~g} \mathrm{~d}^{-1}$ ) compared to other protein supplements. Heat-treated FB had no effect on DMI, milk or protein yield compared to UFB. Only RSE resulted in improvements in dairy cows performance in relation to the control diet.
\end{abstract}

Key words: field beans, heat treatment, protein supplement, pea, rapeseed expeller

\section{Introduction}

The number of organic dairy cows in Sweden increased with around 12500 cows from 2009 to 2011 and within the last 5 years the total number has been rather stable at around 37798 cows (Tuominen et al. 2016). However, the conversion has increased again due to the demand on the market. In Sweden, organic milk delivery has been increasing from around $250000 \mathrm{t}$ in 2010 to $367000 \mathrm{t}$ in 2015 (Tuominen et al. 2016). Supplementation of protein feeds in the diet of dairy cows is essential and the challenge of dairy nutrition is to establish minimal amount of protein required by high producing dairy cows (Huhtanen et al. 2011). High prices and consumers concerns has brought the attention to the use of more economical and ecological ways of producing home-grown protein feeds for animal feed market (Puhakka et al. 2016). Rapeseed meal has been shown to be a good protein source for conventional grass silage based diets (Huhtanen 1998). However, production of organic rapeseed is difficult. Protein supplements that are more resistant to microbial protein degradation in the rumen, yet available for absorption in the small intestine may be beneficial to the supply of extra energy and amino acids needed for high milk production (Faldet and Satter 1991). On many farms, nitrogen efficiency is unnecessarily low and the cost for protein feed is relatively high due to overestimation of the marginal response in milk production in relation to protein supplementation. Legume seeds such as field pea (Pisum sativum) and field bean (Vicia faba) are alternatives that fit well to the organic system. Legume seeds have two advantages: they can be locally produced and can fix atmospheric $\mathrm{N}$ and thereby reduce the need for soil $\mathrm{N}$ fertilisation. Field pea is one of the most important legume seeds for organic farming (Khalili et al. 2002). Field peas have high ruminal protein degradability, high energy value, but have rather low crude protein (CP) content (Loe et al. 2004). Alternatively, field bean (FB) is higher in CP (Luke 2017). There have been studies reporting responses on dairy cows by the use of rumen un-degradable protein (RUP) supplements, such as heat-treated soybeans to increase the protein value of feeds (Faldet and Satter 1991). Protein feeds, differing in RUP, showed to have different flows of RUP and total protein from the rumen (Brito and Broderick 2007). Various physical and chemical treatments have been used to pursue this objective. One of these is a controlled heat application, which allows protein degradation in the rumen to be reduced through denaturation and Maillard reactions, reducing solubility and protein degradation rate in the rumen (Moshtaghi Nia and Ingalls 1995). Heat treatment on legume seeds showed that the supply of nitrogen in the rumen was reduced in which it increased the amount of energy available for rumen microbes (Mogensen et al. 2008, Barchiesi-Ferrari and Anrique 2011). The results from the literature show that there is a need for applied studies exploring the possibilities to better utilise nitrogen in organic dairy production by altering the energy and protein concentration in the diets. 
Utilising locally produced protein feeds will reduce the use of expensive protein concentrates (e.g. soybean meal) and unnecessary losses of nutrients to the environment. At farms, a small scale roasting equipment can be used to heat-treat whole seeds. There is, however, a lack of feeding trials to study the effects of such treatment on locally produced protein feeds in Sweden. We hypothesise that regular protein supplements such as rapeseed expeller can be replaced by legume seeds. We also hypothesise that heat treating locally produced protein feeds will increase the productivity in lactating dairy cows compared to normal protein sources such as peas or rapeseed expeller. The first objective of this study was to evaluate if locally produced legume seeds could improve the performance of lactating dairy cows fed grass silage based diets in organic farming. The second objective was to evaluate if the feeding value of FB could be improved by heat treatment.

\section{Materials and methods}

\section{Experimental design and animals}

The Experiment was conducted at the Department of Agricultural Research for Northern Sweden at the Swedish University of Agricultural Sciences in Umeå (634ㄴ $\left.\mathrm{N} ; 20^{\circ} 17^{\prime} \mathrm{E}\right)$, and approved by the Swedish Ethical Committee on Animal Research in Umeå. Twenty-four lactating Swedish Red dairy cows of mean 95 days in milk (SD = 34.9), and yielding $29.1 \mathrm{~kg}$ milk per day $(S D=6.21)$ were used. The cows were assigned to 4 different blocks according to parity and milk yield. Two blocks were with primiparous cows and the other two with multiparous cows. Within the block, the cows were randomly allocated to 1 of the 6 treatments. The experiment was conducted using a cyclic change over design (Davis and Hall 1969) that included 6 dietary treatments and 3 periods. The formulation of the experimental diets and chemical composition are given in Table 1. The control diet consisted of grass silage and dried rolled barley (60:40, dry matter [DM] basis). In the experimental diets, barley was replaced with rapeseed expeller (RSE; $104 \mathrm{~g} \mathrm{~kg}^{-1}$ diet DM), or isonitrogenous supplements of rolled peas (232 $\mathrm{g} \mathrm{kg}^{-1}$ diet DM), untreated rolled FB (UFB; $140 \mathrm{~g} \mathrm{~kg}^{-1}$ diet DM), heat-treated rolled FB (TFB; $140 \mathrm{~g} \mathrm{~kg}^{-1}$ diet DM) or heat-treated rolled FB, providing the same dietary metabolizable protein (MP) concentrations as UFB (TFB-low; $80 \mathrm{~g} \mathrm{~kg}^{-1}$ diet DM). The silage was a second cut (dominated by timothy grass, and some red clover) with $181 \mathrm{~g} \mathrm{~kg}^{-1} \mathrm{DM}_{\text {of }}$ crude protein (CP) and $494 \mathrm{~g} \mathrm{~kg}^{-1}$ DM of NDF. Heat-treatment of FB was done with a farm-based roasting equipment (R-100E, Roastech, Blomfontein, South Africa). The machine was electrically ( $15 \mathrm{~kW}$ ) heated and consisted of a drum with 3-mm holes. Roasting was conducted at a temperature of $140{ }^{\circ} \mathrm{C}$ and a turning frequency of $50 \mathrm{~Hz}$ which gave a passage time of 7.5-8 minutes. At the outlet of the drum, a cooling container was mounted on the machine to allow air-cooling of the roasted product.

\begin{tabular}{lcccccc}
\multicolumn{7}{l}{ Table 1. Ration ingredients and chemical composition ( $\mathrm{g} \mathrm{kg}^{-1}$ DM unless otherwise noted) } \\
\hline Item & \multicolumn{7}{c}{ Ration } \\
\hline & CON & RSE & PEA & UFB & TFBH & TFBL \\
\cline { 2 - 7 } Grass silage & 600 & 600 & 600 & 600 & 600 & 600 \\
Barley & 400 & 296 & 168 & 260 & 260 & 320 \\
Pea & 0 & 0 & 232 & 0 & 0 & 0 \\
Rapeseed & 0 & 104 & 0 & 0 & 0 & 0 \\
Field bean not-heat treated & 0 & 0 & 0 & 140 & 0 & 0 \\
Field bean heat treated & 0 & 0 & 0 & 0 & 140 & 80 \\
Dry matter, g/kg of fresh matter & 347 & 349 & 349 & 348 & 349 & 349 \\
Organic matter & 921 & 917 & 922 & 920 & 921 & 921 \\
Crude protein & 159 & 187 & 187 & 181 & 183 & 176 \\
Crude fat & 26 & 33 & 24 & 25 & 25 & 25 \\
NDF & 400 & 415 & 365 & 395 & 390 & 393 \\
AAT & 90 & 97 & 94 & 93 & 96 & 93 \\
iNDF & 45 & 56 & 37 & 40 & 40 & 41 \\
Metabolizable energy, MJ/kg of DM & 11.8 & 11.8 & 12.1 & 11.9 & 12.0 & 11.9 \\
\hline
\end{tabular}

$\mathrm{CON}$ = control; RSE = rapeseed expeller; UFB = field bean not heat treated; TFBH = field bean heat treated high level; TFBL = field bean heat treated low level; NDF = neutral detergent fibre; iNDF = indigestible NDF; AAT = amino acids absorbed in the intestine, metabolizable protein, tabulated values calculated from feed tables (Tuori et al. 1996, Luke 2017) 
Each experimental period lasted for $21 \mathrm{~d}$ and was divided in $14 \mathrm{~d}$ of adaptation and $7 \mathrm{~d}$ for data recording and sampling. The cows were housed in an insulated, loose-housing barn, and were milked twice a day at 06.00 and 15.00, they were fed TMR in ad libitum. The DM of the silage and other feed ingredients were determined twice weekly by drying the samples at $60{ }^{\circ} \mathrm{C}$ for $48 \mathrm{~h}$ in order to account for the changes in the DM content and to update the computer system at our dairy farm. A stationary feed mixer processed the rations which were then delivered with automatic feeder wagons into feed troughs 4 times a day (0330, 0800, 1300 and $1730 \mathrm{~h})$. During the entire trial, each cow had access to the same 3 feed troughs. The amount of feed delivered to the feed troughs was monitored daily to allow ad libitum feeding.

\section{Recordings and sampling}

Individual feed intake was automatically recorded daily throughout the trial with the Roughage intake control system (Insentec B. V., Marknesse, the Netherlands). The cows were weighed after morning milking on d 19 to 21 in every period. Assessment of the body condition of the cows were according to the scheme of Edmonson et al. (1989) that was made on d 21 in each period.

Silage, barley, peas, rapeseed expeller, and FB was sampled on d 16,19 and 21 in every period and stored in $-20^{\circ} \mathrm{C}$ until further processed. Frozen silage samples were ground to pass a $20 \mathrm{~mm}$ sieve in a cutter mill (SM 2000, Retsch Ltd., Haan, Germany), and a part was returned to the freezer for later analyses of silage fermentation quality. All feed samples were oven dried at $60{ }^{\circ} \mathrm{C}$ for $48 \mathrm{~h}$. The dried samples were ground to pass through a $2 \mathrm{~mm}$ and a 1 $\mathrm{mm}$ sieve by the same cutter mill for the different analytical purposes. Silage samples were analyzed separately for all 3 periods. Samples of pea, rapeseed expeller, untreated and heat-treated FB and barley from period 1 to 3 were pooled before analysis.

Milk yield was recorded daily morning and evening with gravimetric milk recorders (S.A. Christensen and Co Ltd, Kolding, Denmark). Milk samples were collected at 4 consecutive milking from the afternoon on $d 19$ until the morning of $\mathrm{d} 21$ in every period.

Mass fluxes of methane $\left(\mathrm{CH}_{4}\right)$ and carbon dioxide $\left(\mathrm{CO}_{2}\right)$ are measured by GreenFeed system (C-Lock Inc., Rapid City, SD). The details of the system is described by Huhtanen et al. (2015). In short, the animals are encouraged to the system by giving them small amounts of concentrates as from automatic concentrate feeders. In the present study the system was programmed allowing for each animal a visit every $5 \mathrm{~h}$, i.e. if the cows used all opportunities to visit the GreenFeed the time of visit advanced $1 \mathrm{~h}$ each day. The cows were given 8 doses of $50 \mathrm{~g}$ concentrates every $40 \mathrm{~s}$. Airflow rates and gas concentrations are measured continuously, and other environmental parameters (temperature, air pressure, moisture) are recorded. Using the gas sensor information, a volumetric flux $\left(I \mathrm{~min}^{-1}\right)$ of gases emitted by the animal can then be calculated. The system also records head position during the visit, and data with inappropriate head position is filtered out.

\section{Chemical analysis}

Silage samples were collected twice per week and concentrate samples were collected once per week and pooled per period. Silage samples were oven dried at $105{ }^{\circ} \mathrm{C}$ in order to correct for the DM loss of volatile fatty acids (Huida et al. 1986). All feed samples were oven dried at $60^{\circ} \mathrm{C}$ for $48 \mathrm{~h}$ and stored for later analysis of chemical composition. Ash determination followed at $500^{\circ} \mathrm{C}$ for 4 hours. Samples of the concentrate feeds and grass silage were analyzed by Dairy One Forage Lab (Ithaca, NY, USA, http://dairyone.com/analytical-services/feed-and-forage/feed-composition-library/) to determine their chemical composition (Table 2). Amino acids absorbed in the intestine (AAT) known as MP was calculated using values from feed tables (Tuori et al. 1996, Luke 2017).

Concentrations of indigestible NDF (iNDF) was determined according to Huhtanen et al. (1994) from replicated samples using 2 cows fed a TMR of $60 \%$ silage and $40 \%$ of a commercial concentrate mix (Solid 220, Lantmännen, Malmö, Sweden). The frozen silage samples were analyzed for concentrations of ammonium-N, volatile fatty acids (VFA) and lactic acid (Ericson and André 2010). The milk samples were analyzed for concentration of fat, protein, lactose, and urea using a near infrared reflectance analyzer (Eurofins Steins Laboratory Ltd, Jönköping, Sweden).

Even though some recordings were done daily, all results are based on the recordings and samplings done during the last $7 \mathrm{~d}$ in each period. Energy corrected milk (ECM) was calculated according to Sjaunja et al. (1990). 
Table 2. Chemical composition, $\mathrm{g} \mathrm{kg}^{-1}$ of dry matter (DM) unless otherwise noted of ingredients

\begin{tabular}{|c|c|c|c|c|c|c|}
\hline Item & Barley & Rapeseed expeller & Pea & UFB & TFB & Grass silage \\
\hline $\mathrm{DM}, \mathrm{g} \mathrm{kg}^{-1}$ of fresh matter & 889 & 908 & 902 & 892 & 916 & 276 \\
\hline Organic matter & 967 & 929 & 972 & 964 & 966 & 890 \\
\hline $\mathrm{EE}$ & 19 & 87 & 11 & 11 & 12 & 20 \\
\hline Crude protein & 126 & 394 & 246 & 286 & 298 & 181 \\
\hline NDF & 259 & 404 & 110 & 221 & 186 & 494 \\
\hline iNDF & 34.4 & 146 & 0 & 3.2 & 0.7 & 51.5 \\
\hline Acid detergent fibre & 102 & 262 & 73 & 167 & 139 & 314 \\
\hline Non fibrous carbohydrate & 567 & 44 & 605 & 445 & 471 & 185 \\
\hline Water soluble carbohydrate & 18 & 90 & 43 & 21 & 112 & \\
\hline Starch & 503 & 16 & 374 & 271 & 248 & \\
\hline AAT & 98 & 169 & 116 & 123 & 144 & 84 \\
\hline Metabolizable energy, $\mathrm{MJ} \mathrm{kg}^{-1}$ of DM & 13.2 & 12.7 & 14.4 & 13.9 & 14.2 & 10.9 \\
\hline \multicolumn{7}{|l|}{ Silage fermentation quality, $\mathrm{g} \mathrm{kg}^{-1} \mathrm{DM}$} \\
\hline Lactic acid & & & & & & 43.0 \\
\hline Acetic acid & & & & & & 7.61 \\
\hline Propionic acid & & & & & & 0.39 \\
\hline Butyric acid & & & & & & 0.20 \\
\hline Ethanol & & & & & & 1.23 \\
\hline Formic acid & & & & & & 0.20 \\
\hline Ammonia - $\mathrm{N}, \mathrm{g} \mathrm{kg}^{-1} \mathrm{~N}$ & & & & & & 49.2 \\
\hline $\mathrm{pH}$ & & & & & & 3.84 \\
\hline
\end{tabular}

$\mathrm{DM}=$ dry matter; NDF = neutral detergent fibre; $\mathrm{NNDF}=$ indigestible neutral detergent fibre; $\mathrm{UFB}=$ untreated field been; $\mathrm{TFB}=$ heat treated field been. $\mathrm{EE}=$ ether extract for the silage is tabulated values (Spörndly 2003), for concentrate ingredients ether extract was analyzed; AAT = amino acids absorbed in the intestine or metabolizable protein, tabulated values calculated from feed tables (Tuori et al. 1996, Luke 2017)

\section{Statistical analysis}

The results were analyzed with the MIXED procedure of Statistical Analysis Systems (SAS for Windows, version 9.3, SAS Institute, Cary, NC) with the statistical model:

$$
Y_{i j k}=\mu+B_{i}+D_{j}+P_{k}+B_{i}\left(D_{j}\right)+B_{i}\left(P_{k}\right)+\varepsilon_{i j k}
$$

where $Y_{i j k}$ is the dependent variable, $\mu$ is the mean for all observations, $B_{i}$ is the effect of block $i, D_{i}$ is the effect of diet $j, P_{k}$ is the effect of period $k, B_{i}\left(D_{j}\right)$ is the effect of block i within diet $j, B_{i}\left(P_{k}\right)$ is the effect of block i within period $k$ and $e_{i j k l} \sim N\left(0, \sigma_{\varepsilon}{ }^{2}\right)$ is the random residual error. For treatment comparison the following contrasts were used: the effect of protein supplementation that was: control (CON) vs. other diets (O), rapeseed expeller (R) vs. legume seeds excluding CON, untreated field beans vs. peas, untreated field beans vs. treated field beans- low level, and untreated field beans vs. treated field beans - high level. The differences were considered significant at $p \leq 0.05$.

\section{Results \\ Experimental feeds}

Protein supplementation increased dietary CP concentration from 159 to $187 \mathrm{~g} \mathrm{~kg}^{-1} \mathrm{DM}$ as given in Table 1. Low acids and ammonia $\mathrm{N}$ indicates the rather good quality silage as shown in Table 2. The iNDF concentrations of the diets were rather similar (Table 1). The chemical compositions of the experimental dietary ingredients are given in Table 2. Grass silage had a DM of $276 \mathrm{~g} \mathrm{~kg}^{-1}$ on fresh basis. Heat treated FB had slightly a higher protein content compared to the untreated field bean (298 vs. $286 \mathrm{~g} \mathrm{~kg}^{-1} \mathrm{DM}$, Table 2). 
Table 3. The effect of dietary treatments on feed intake and nutrient consumption ( $\left.\mathrm{kg} \mathrm{d}^{-1}\right)$ of dairy cows

\begin{tabular}{|c|c|c|c|c|c|c|c|c|c|c|c|c|}
\hline \multirow[t]{2}{*}{ Item } & \multicolumn{7}{|c|}{ Ration } & \multicolumn{5}{|c|}{ Contrasts $(p)$} \\
\hline & CON & RSE & PEA & UFB & TFBH & TFBL & SEM & $\begin{array}{c}\text { C vs. } \\
0\end{array}$ & R vs. O & $\begin{array}{c}\text { UFB vs. } \\
\text { PEA }\end{array}$ & $\begin{array}{c}\text { UFB vs. } \\
\text { TFBL }\end{array}$ & $\begin{array}{c}\text { UFB vs. } \\
\text { TFBH }\end{array}$ \\
\hline Total DMI & 18.2 & 19.0 & 19.0 & 18.7 & 18.7 & 18.6 & 0.37 & 0.13 & 0.33 & 0.58 & 0.80 & 0.98 \\
\hline Silage DMI & 10.2 & 10.9 & 10.8 & 10.7 & 10.6 & 10.5 & 0.25 & 0.04 & 0.37 & 0.93 & 0.40 & 0.50 \\
\hline $\mathrm{CP}$ & 2.90 & 3.55 & 3.44 & 3.35 & 3.32 & 3.15 & 0.072 & $<0.01$ & $<0.01$ & 0.33 & 0.04 & 0.79 \\
\hline NDF & 7.11 & 7.66 & 6.94 & 7.23 & 7.23 & 7.26 & 0.154 & 0.31 & $<0.01$ & 0.17 & 0.90 & 0.99 \\
\hline ¡NDF & 0.980 & 1.148 & 0.828 & 0.835 & 0.887 & 0.953 & 0.0242 & 0.13 & $<0.01$ & 0.21 & 0.03 & 0.70 \\
\hline OM & 17.0 & 17.6 & 17.5 & 17.3 & 17.3 & 17.2 & 0.34 & 0.15 & 0.44 & 0.53 & 0.84 & 0.98 \\
\hline AAT & 1.66 & 1.85 & 1.78 & 1.75 & 1.75 & 1.71 & 0.035 & $<0.01$ & $<0.01$ & 0.51 & 0.40 & 0.96 \\
\hline $\mathrm{ME}, \mathrm{MJ} \mathrm{d}^{-1}$ & 219 & 224 & 231 & 223 & 223 & 222 & 4.50 & 0.18 & 0.98 & 0.17 & 0.87 & 0.97 \\
\hline
\end{tabular}

$\mathrm{DMI}$ = dry matter intake; CON = control; RSE = rapeseed expeller; UFB = field bean untreated; TFBH = field bean heat treated high level; $\mathrm{TFBL}=$ field bean heat treated low level; $\mathrm{SEM}=$ standard error of mean; $\mathrm{C}$ vs. $\mathrm{O}=\mathrm{CON}$ vs. other diets; $\mathrm{R}$ vs. $\mathrm{O}=\mathrm{RSE}$ vs. other diets excluding $\mathrm{CON}$; $\mathrm{CP}=$ crude protein; NDF = neutral detergent fibre; iNDF = indigestible NDF; OM = organic matter; $A A T=$ amino acids absorbed in the intestine or metabolizable protein, tabulated values calculated using feed tables (Tuori et al. 1996, Luke 2017); ME = metabolizable energy

\section{Nutrient intake and milk production}

Protein supplementation had no effect ( $p=0.13$ ) on DM intake, however CP intake was greater $(p<0.01)$ for the protein feeds compared to the control diet without any protein supplement (Table 3$)$. The RSE protein supplemented diet showed greater estimates of amino acid (AAT) intake $(p<0.01)$ compared to other diets excluding the control diet (Table 3). Heat-treated FB had no effect on DMI, milk or protein yield compared to UFB. Milk yield or ECM yield, were not significantly different for the control diet compared to the protein supplemented diets (Table 4). This was mainly because peas or FB supplemented diets did not increase milk and protein yield compared to the control diet. The RSE protein supplemented treatment increased milk $\left(24.8 \mathrm{vs} .23 .6 \mathrm{~kg} \mathrm{~d}^{-1}\right)$ and protein yield (913 vs. $863 \mathrm{~g} \mathrm{~d}^{-1}$ ) compared to other protein supplements (Table 4). Milk nitrogen efficiency decreased and milk urea increased with protein supplementation compared to the control diet ( $254 \mathrm{vs.} 294 \mathrm{~g} \mathrm{~kg}^{-1}$ and 3.01 vs. 3.92 $\mathrm{mmol} \mathrm{I}^{-1}$, respectively) as shown in Table 4.

Table 4. Mean treatment effects on milk production and nitrogen efficiency between diets

\begin{tabular}{|c|c|c|c|c|c|c|c|c|c|c|c|c|}
\hline \multirow{2}{*}{$\begin{array}{ll} & \text { Item } \\
\text { Yield } & \end{array}$} & \multicolumn{6}{|c|}{ Ration } & \multicolumn{6}{|c|}{ Contrasts $(p)$} \\
\hline & CON & RSE & PEA & UFB & TFBH & TFBL & SEM & $\begin{array}{c}\text { C vs. } \\
0\end{array}$ & $\begin{array}{c}\text { R vs. } \\
\mathrm{O}\end{array}$ & $\begin{array}{l}\text { UFB vs. } \\
\text { PEA }\end{array}$ & $\begin{array}{c}\text { UFB vs. } \\
\text { TFBL }\end{array}$ & $\begin{array}{c}\text { UFB vs. } \\
\text { TFBH }\end{array}$ \\
\hline Milk, $\mathrm{kg} \mathrm{d}^{-1}$ & 23.5 & 24.8 & 23.0 & 23.7 & 23.8 & 23.8 & 0.90 & 0.49 & 0.02 & 0.30 & 0.90 & 0.85 \\
\hline $\mathrm{ECM}, \mathrm{kg} \mathrm{d}^{-1}$ & 24.6 & 26.6 & 24.9 & 25.8 & 25.8 & 25.3 & 0.91 & 0.18 & 0.17 & 0.40 & 0.97 & 0.62 \\
\hline Protein, $\mathrm{g} \mathrm{d}^{-1}$ & 873 & 913 & 833 & 863 & 873 & 887 & 28.2 & 0.95 & 0.02 & 0.24 & 0.35 & 0.71 \\
\hline Fat, $\mathrm{g} \mathrm{d}^{-1}$ & 993 & 1098 & 1043 & 1074 & 1075 & 1033 & 47.1 & 0.13 & 0.38 & 0.60 & 0.50 & 0.99 \\
\hline Lactose, $\mathrm{g} \mathrm{d}^{-1}$ & 1080 & 1135 & 1062 & 1102 & 1108 & 1082 & 41.5 & 0.50 & 0.08 & 0.25 & 0.57 & 0.84 \\
\hline \multicolumn{13}{|l|}{ Concentration } \\
\hline Fat, $\mathrm{g} \mathrm{kg}^{-1}$ & 43.3 & 44.8 & 45.4 & 46.1 & 45.5 & 44.1 & 1.63 & 0.17 & 0.72 & 0.71 & 0.30 & 0.76 \\
\hline Protein, $\mathrm{g} \mathrm{kg}^{-1}$ & 37.6 & 37.3 & 36.6 & 36.9 & 36.9 & 37.5 & 0.53 & 0.049 & 0.29 & 0.44 & 0.07 & 0.99 \\
\hline Lactose, $\mathrm{g} \mathrm{kg}^{-1}$ & 46.1 & 45.9 & 46.1 & 46.5 & 46.5 & 45.6 & 0.35 & 0.99 & 0.37 & 0.23 & 0.02 & 0.82 \\
\hline Urea, mmol l-1 & 3.01 & 3.79 & 3.94 & 3.90 & 4.42 & 3.57 & 0.154 & $<0.01$ & 0.16 & 0.80 & 0.03 & $<0.01$ \\
\hline $\mathrm{FE}, \mathrm{kg} \mathrm{kg}^{-1}$ & 1.35 & 1.40 & 1.32 & 1.34 & 1.37 & 1.36 & 0.046 & 0.77 & 0.14 & 0.60 & 0.62 & 0.52 \\
\hline MNE, $\mathrm{g} \mathrm{kg}^{-1}$ & 294 & 253 & 240 & 245 & 255 & 277 & 8.6 & $<0.01$ & 0.82 & 0.42 & $<0.01$ & 0.09 \\
\hline Body weight, kg & 643 & 640 & 637 & 640 & 636 & 644 & 14.2 & 0.61 & 0.95 & 0.76 & 0.62 & 0.70 \\
\hline Body condition score & 3.51 & 3.52 & 3.53 & 3.53 & 3.51 & 3.54 & 0.045 & 0.65 & 0.85 & 0.97 & 0.92 & 0.68 \\
\hline
\end{tabular}




\section{Gas emissions}

Diet had no significant effect on total $\mathrm{CH}_{4}$ emissions (Table 5). The RSE supplemented diet tended to decrease ( $p=$ 0.09 ) $\mathrm{CH}_{4}$ production compared to other protein supplements ( $383 \mathrm{vs.} 399 \mathrm{~g} \mathrm{~d}^{-1}$ ) as given in Table 5. There was no significant differences on $\mathrm{CH}_{4}$ per $\mathrm{kg}$ of ECM between the diets.

Table 5. Mean treatment effects on methane and carbon dioxide emission between diets

\begin{tabular}{|c|c|c|c|c|c|c|c|c|c|c|c|c|}
\hline \multirow[t]{2}{*}{ Item } & \multicolumn{7}{|c|}{ Ration } & \multicolumn{5}{|c|}{ Contrasts $(p)$} \\
\hline & CON & RSE & PEA & UFB & TFBH & TFBL & SEM & C vs. $\mathrm{O}$ & R vs. O & $\begin{array}{l}\text { UFB } \\
\text { VS. } \\
\text { PEA }\end{array}$ & $\begin{array}{l}\text { UFB } \\
\text { vS. } \\
\text { TFBL }\end{array}$ & $\begin{array}{l}\text { UFB } \\
\text { vS. } \\
\text { TFBH }\end{array}$ \\
\hline $\mathrm{CH}_{4}, \mathrm{~g} \mathrm{~d}^{-1}$ & 390 & 383 & 397 & 389 & 403 & 406 & 9.6 & 0.53 & 0.09 & 0.45 & 0.12 & 0.20 \\
\hline $\mathrm{CH}_{4}, \mathrm{~g} \mathrm{ECM}^{-1}$ & 16.0 & 15.2 & 16.7 & 15.9 & 16.1 & 16.2 & 0.75 & 0.99 & 0.13 & 0.30 & 0.71 & 0.80 \\
\hline $\mathrm{CH}_{4}, \mathrm{~g} \mathrm{DMI}^{-1}$ & 21.4 & 20.4 & 21.0 & 20.8 & 21.6 & 22.0 & 0.57 & 0.71 & 0.11 & 0.78 & 0.10 & 0.22 \\
\hline $\mathrm{CO}_{2}, \mathrm{~g} \mathrm{~d}^{-1}$ & 11472 & 11839 & 11986 & 11786 & 12095 & 11716 & 217.0 & 0.03 & 0.75 & 0.40 & 0.76 & 0.19 \\
\hline $\mathrm{CH}_{4} \mathrm{CO}_{2}^{-1}$ & 0.034 & 0.033 & 0.033 & 0.033 & 0.033 & 0.035 & 0.0006 & 0.44 & 0.19 & 0.91 & 0.03 & 0.62 \\
\hline
\end{tabular}

$\mathrm{CH}_{4}=$ Methane; $\mathrm{CO}_{2}$ = carbon dioxide; $\mathrm{ECM}$ = energy corrected milk; CON = control; $\mathrm{RSE}$ = rapeseed expeller; UFB = field bean untreated; $\mathrm{TFBH}=$ field bean heat treated high level; TFBL = field bean heat treated low level; $\mathrm{SEM}=$ standard error of mean; $\mathrm{C}$ vs. $\mathrm{O}=\mathrm{CON}$ vs. other diets; $\mathrm{R}$ vs. $\mathrm{O}=\mathrm{RSE}$ vs. other diets excluding CON

\section{Discussion}

The demand of organic milk in Sweden is increasing. Organic farming is based on the use of forages for dairy cows where application of fertilizers are not permitted. The potential of conventionally produced RSE and organically grown legume seeds on the lactation performance of Swedish dairy cows fed grass silage-based diets were currently assessed. Since positive responses of heat treating legume seeds to improve RUP has been demonstrated in the literature (Brask et al. 2013, Vaga et al. 2017), we also used the technique to improve the quality of FB in this study. Our hypothesis of increased production response to added legume seeds was not demonstrated except for the RSE protein supplemented diet. In contrast the control diet without any protein supplement showed as good milk production compared to other diets with supplemented protein.

\section{Effect on dry matter intake}

The DMI was not affected by the supplementation of protein sources to the diets compared to the control diet. This was in line with the findings by Faldet and Satter (1991) who did not see any significant change of DMI on cows fed either soybean meal or heat treated soybean meal. However, the majority of studies in the literature report that protein supplementation increases DMI (Khalili et al. 2002, Huhtanen et al. 2011) which has been related to faster rate of fibre digestion in the rumen (Oldham 1984), and possibly to improved balance between AA and metabolizable energy (ME) in absorbed nutrients. The latter increases production that pulls intake (Huhtanen et al. 2011). In contrast to our findings on DMI, the substitution of RSE with FB linearly decreased DMI with a greater effect at high crude protein levels (Puhakka et al. 2016). Lower DMI in their study with FB can be related to poorer balance between AA and ME. Choung and Chamberlain (1993) reported that inclusion of fishmeal increased DMI and production responses whereas, the feather meal did not. Faldet and Satter (1991) reported an overall CP intake of $175 \mathrm{~g} \mathrm{~kg}^{-1} \mathrm{DM}$ within their experimental diets with heat treated soybeans (roasted) which is $7.8 \mathrm{~g} \mathrm{~kg}^{-1} \mathrm{DM}$ units lower than the current study (excluding the control diet).

\section{Effect on milk production}

In the current study supplementation with RSE showed positive responses that has also been shown by Huhtanen et al. (2011) in a meta-analysis, in which production responses in dairy cows were greater with rapeseed meal compared to soybean meal. However, relatively small responses with the RSE in the current study might relate to the low production level (on average $25.5 \mathrm{ECM}, \mathrm{kg} \mathrm{d}^{-1}$ ) and the high quality of the grass silage used in the current study. Using different physical forms of rapeseed in dairy cows fed grass silage also showed no significant improvements in milk production (Brask et al. 2013), by considering that milk yield was $5.2 \mathrm{I} \mathrm{d}^{-1}$ greater at the beginning of the experiment for the dairy cows used by Brask et al. (2013) compared to the current study. In the study by Brask et al. (2013), to compensate for the CP level, rapeseed meal was included in all diets including the control and that other physical forms of rapeseed were included in diets excluding the control. The findings by Faldet 
and Satter (1991) are more comparable to the heat treated FB (2 levels) with the untreated FB diet (Table 4). Milk and protein yield was greater with the RSE diet compared to all other diets in the current study that is in line with the findings of Puhakka et al. (2016). In our study, the RSE diet showed higher milk yield $\left(1.1 \mathrm{~kg} \mathrm{~d}^{-1}\right)$ compared to other protein supplemented diets. Khalili et al. (2002) showed higher milk and protein yield for the diet supplemented with rapeseed meal compared to the control diet with a mixture of oats and barley. However, the lower than expected production response to added protein sources was also reported by Gidlund et al. (2015) in which the added rapeseed meal did not show greater production responses on dairy cows fed highly digestible grass silages compared to the control diet with only crimped barley and no protein feed. Previous studies of production responses in dairy cows did not find differences between FB and rapeseed meal (Ingalls and McKirdy 1974). Earlier studies suggested that pea could successfully replace other protein supplements such as soybean meal without having negative effects on milk production (Petit et al. 1997). However, the quality of pea protein is less ideal since it contains more rumen degradable protein and less MP than rapeseed meal (Khalili et al. 2002). Our findings did not show any improvements on milk yield or ECM when FB was heat treated compared to the UFB diet. The non-significant effect of milk yield among diets in the current study might attribute to the extent of heat treatment. Faldet and Satter (1991) showed a variation of 36 to 58\% of undegraded intake of protein, as a percentage of total crude protein for 13 samples tested on soybeans. In agreement with our findings, several other experiments have shown that heat treatment does not affect milk fat (Pires et al. 1996) or milk protein content (Bertilsson et al. 1994). However our results contradicted to the findings by Faldet and Satter (1991) who showed an improvement on milk yield for the heat treated soybean diet compared to the raw soybeans or soybean meal diet. In line with our results, Mielke and Schingoethe (1981) reported no response in milk production of cows fed heat treated soybeans. Schingoethe et al. (1988) reported a depression of milk fat for dairy cows fed heated soybeans whereas Faldet and Satter (1991) and our study showed that milk fat percentage was similar among treatments. Fat yield was higher for the heated soybean diet in the study by Faldet and Satter (1991) whereas no effect on fat yield was detected in our study among different diets. Concentration of protein in milk was not different among diets in this study. This is in contrast to the study of Faldet and Satter (1991) in which reported a depression in milk protein for cows consuming the heated soybean diet compared to the soybean meal diet. Puhakka et al. (2016) found that replacing rapeseed meal with FBs decreased milk yield and protein concentration supporting their hypothesis that lower potential of FBs compared with rapeseed meal.

Milk urea was greater for the protein feeds compared to the control diet with no supplementation of protein feeds, and the values were greater for the TFB-high compared to the untreated field bean treatment. This is in line with the findings by Puhakka et al. (2016) reporting a greater milk urea concentration for the FB compared to rapeseed which showed better utilization of protein from the rapeseed meal. Vanhatalo et al. (2004) showed a decrease in milk yield when rapeseed was replaced with peas, but in the current study the pea diet did not show any decrease in milk yield compared to other protein feeds or even with the control diet with no protein source.

\section{Effect on methane emissions}

The tendency for decreased $\mathrm{CH}_{4}$ production for the RSE diet could be due to the higher fat concentration of the RSE (Table 1 and 2) which influences the amount of $\mathrm{CH}_{4}$ produced (Beauchemin et al. 2009). In a meta-analysis conducted by Ramin and Huhtanen (2013) fat in the diet decreases $\mathrm{CH}_{4}$ production by three mechanisms. Fat generally influences $\mathrm{CH}_{4}$ production by attributing to decreased supply of fermentable substrate rather than to a direct effect on methanogenesis. The bio-hydrogenation of unsaturated fatty acids utilizes $\mathrm{H}_{2}$ available for $\mathrm{CH}_{4}$ production. In addition, increased dietary fat concentration can influence rumen fermentation by increasing the proportion of propionate at the expense of acetate or butyrate. In a recent study conducted by Gidlund et al. (2015) diets supplemented with either soybean meal or canola meal at both high and low level, numerically decreased $\mathrm{CH}_{4}$ production compared to the control diet with only crimped barley and no protein feed. Brask et al. (2013) found that inclusion of different physical forms of rapeseed as fat supplement decreased $\mathrm{CH}_{4}$ production by an average of $79 \mathrm{Id}^{-1}$ compared to the control diet. The relatively small effect on $\mathrm{CH}_{4}$ production in the current study might relate to the smaller amount of crude fat in RSE as compared to different physical forms of rapeseed used by Brask et al. (2013).

\section{Effect of heat treatment method}

Huhtanen et al. (2011) and earlier Ipharraguerre and Clarkfound (2005) reported that the effect of chemical and physical treatments to reduce CP degradability do not result in expected improvements in CP supply to the small intestine. Our study is in line with the findings of Huhtanen et al. (2011) since the performance of the dairy cows did not change by heat treating FB. Results from an organic farming study with high-yielding dairy cows indicate that 
toasting decreases effective rumen protein degradability for diets including toasted lupins, barley and soybeans (Mogensen et al. 2008). They reported that toasting lupins tended to increase milk yield compared to the untreated lupins, whereas toasting of soybeans did not show any improvements. Large variation does exist in the literature of heat treatment obtained by commercial processors. The variation is most likely attributed to the temperature and time of heating. In a recent study, Vaga et al. (2017) demonstrated that untreated legume seeds did not change utilizable crude protein. Heat treatment increased depending on method (oven vs. autoclave), temperature and length of treatment. Some treatments were too strong as indicated by high acid detergent insoluble nitrogen. In the case of FB methionine can become limiting (only about $25 \%$ of milk methionine is on CP basis from the diet). The discrepancy between studies on the effect of heat treatment of feeds and performance of dairy cows and supply of MP can vary among feeds. In an in vitro evaluation Vaga et al. (2017) found that treatment method (autoclave vs. oven), temperature and the length of treatment affected the concentration of utilizable CP. It should be noted that increasing temperature and treatment period will increase processing costs and may decrease the concentrations of essential amino acids and decreases intestinal digestibility of undegraded CP.

In the current study heat treatment did not show a positive response on the lactation performance of dairy cows. Based on the results of the meta-analysis conducted by Huhtanen et al. (2011), very seldom positive effects of heat treatment have been observed. This can be due to reduced digestibility of supplementary protein in the intestine, depression in microbial protein synthesis in the rumen, reduced concentrations of lysine and that other nutrients, especially energy that will limit the utilization of amino acids (Huhtanen et al. 2011).

\section{Conclusions}

This study showed that no improvement on lactation performance of dairy cows were achieved by the inclusion of locally produced legume seeds, heat treated or untreated FB compared to a control diet without any protein supplement, provided that rumen degradable protein requirements were met. Only rapeseed expeller supplementation resulted in improvements in animal performance compared to the control diet. Based on the results from the current study it can be concluded that in organic systems omitting protein supplementation can be a relevant option due to low, if any, production responses and increased feed costs provided that the supply of rumen degradable protein is met.

\section{Acknowledgments}

The authors would like to thank all the farm crew for caring of the cows, the laboratory staff at the Department of Agricultural Research for Northern Sweden (Umeå, Sweden) for conducting laboratory analysis. The study was partly funded by the Swedish Board of Agriculture SJV. The support of Fredrik Fogelberg at the Technical Research Institute of Sweden (SP) with the bean toaster is highly acknowledged.

\section{References}

Brask, M., Lund, P., Weisbjerg, M. R., Hellwing, A.L.F., Poulsen, M., Larsen, M. K. \& Hvelplund, T. 2013. Methane production and digestion of different physical forms of rapeseed as fat supplements in dairy cows. Journal of Dairy Science 96: 2356-2365. https://doi.org/10.3168/jds.2011-5239

Barchiesi-Ferrari, C. \& Anrique, R. 2011. Ruminal degradability of dry matter and crude protein from moist dehulled lupin and extruded rapeseed meal. Chilean Journal of Agricultural Research 71: 430-436. https://doi.org/10.4067/S0718-58392011000300014

Beauchemin, K.A., McGinn, S.M., Benchaar C. \& Holtshausen, L. 2009. Crushed sunflower, flax, or canola seeds in lactating dairy cow diets: Effects on methane production, rumen fermentation, and milk production. Journal of Dairy Science 92: $2118-2127$. https://doi.org/10.3168/jds.2008-1903

Bertilsson, J., Gonda, H. \& Lindberg, J.E. 1994. Effect of level and degradability of rapeseed meal in rations for dairy cows. Acta Agriculturae Scand Section A 44: 222-229.

Brito, A.F. \& Broderick, G.A. 2007. Effects of different protein supplements on milk production and nutrient utilization in lactating dairy cows. Journal of Dairy Science 90: 1816-1827. https://doi.org/10.3168/jds.2006-558

Choung, J.J \& Chamberlain, D. G. 1993. The effects of abomasal infusions of casein or soya-bean-protein isolate on the milk production of dairy cows in mid-lactation. British Journal of Nutrition 69: 103-115. https://doi.org/10.1079/BJN19930013

Davis, A.W. \& Hall, W.B. 1969. Cyclic change-over designs. Biometrika 56: 283-293. https://doi.org/10.1093/biomet/56.2.283

Edmonson, A.J., Lean, I.J., Weaver, L.D., Farver, T. \& Webster, G. 1989. A body condition scoring chart for Holstein dairy-cows. Journal of Dairy Science 72: 68-78. https://doi.org/10.3168/jds.S0022-0302(89)79081-0 
Ericsson, B. \& André, J. 2010. HPLC- applications for agricultural and animal science. In: Udén, P., Eriksson, T., Müller, C.E., Spörndly, R. \& Liljeholm, M. (eds.). Proceedings of the 1st Nordic Feed Science Conference, in June in Uppsala, Sweden. Uppsala: Repro SLU. p. 23.

Faldet, M.A. \& Satter, L.D. 1991. Feeding heat-treated full fat soybeans to cows in early lactation. Journal of Dairy Science 74: 3047-3054 https://doi.org/10.3168/jds.S0022-0302(91)78490-7

Gidlund, H., Hetta, M., Krizsan, S.J., Lemosquet, S. \& Huhtanen, P. 2015. Effects of soybean meal or canola meal on milk production and methane emissions in lactating dairy cows fed grass silage-based diets. Journal of Dairy Science 98: 8093-8106. https:// doi.org/10.3168/jds.2015-9757

Huhtanen, P. 1998. Supply of nutrients and productive responses in dairy cows given diets based on restrictively fermented silage. Agricultural and Food Science Finland 7: 219-250.

Huhtanen, P., Cabezas-Garcia, E., Utsumi, S. \& Zimmerman, S. 2015. Comparison of methods to determine methane emissions from dairy cows in farm conditions. Journal of Dairy Science 98: 3394-3409. https://doi.org/10.3168/jds.2014-9118

Huhtanen, P., Hetta, M. \& Swensson, C. 2011. Evaluation of canola meal as a protein supplement for dairy cows: A review and a meta-analysis. Canadian Journal of Animal Science 91: 529-543. https://doi.org/10.4141/cjas2011-029

Huhtanen, P., Kaustell, K. \& Jaakkola, S. 1994. The use of internal markers to predict total digestibility and doudenal flow of nutrients in cattle given 6 different diets. Animal Feed Science and Technology 48: 211-227. https://doi.org/10.1016/0377-8401(94)90173-2

Huida, L., Väätäinen, H. \& Lampila, M. 1986. Comparison of dry matter contents in grass silages as determined by oven drying and gas chromatographic water analysis. Annales Agriculturae Fenniae 25: 215-230.

Ingalls, J. R. \& McKirdy, J. A. 1974. Faba bean as a substitute for soybean meal or rapeseed meal in rations for lactating cows. Canadian Journal of Animal Science 54: 87-89. https://doi.org/10.4141/cjas74-013

Ipharraguerre, I.R. \& Clark, J.H. 2005. Impacts of the source and amount of crude protein on the intestinal supply of nitrogen fractions and performance of dairy cows. Journal of Dairy Science 88 (E Suppl.): E22-E37.

Khalili, H., Kuusela, E., Suvitie, M. \& Huhtanen, P. 2002. Effect of protein and energy supplements on milk production in organic farming. Animal Feed Science and Technology 98: 103-119. https://doi.org/10.1016/S0377-8401(02)00005-6

Luke 2017. Feed tables and nutrient requirements. www.luke.fi/feedtables. Accessed 1 April 2017.

Loe, E.R., Bauerl, M.L., Lardy, G.P., Caton, J.S. \& Berg, P.T. 2004. Field pea (Pisum sativum) inclusion in corn-based lamb finishing diets. Small Ruminant Research 53: 39-45. https://doi.org/10.1016/j.smallrumres.2003.08.020

Mielke, C.D. \& Schingoethe, D.J. 1981. Heat treated soybeans for lactating cows. Journal of Dairy Science 64: 1579. https://doi. org/10.3168/jds.S0022-0302(81)82728-2

Mogensen, L., Lund, P., Kristensen, T. \& Weisbjerg, M. R. 2008. Effects of toasting blue lupins, soybeans or barley as supplement for high-yielding, organic dairy cows fed grass-clover silage ad libitum. Livestock Science 115: 249-257. https://doi.org/10.1016/j. livsci.2007.08.011

Moshtaghi Nia, S.A. \& Ingalls, J.R. 1995. Influence of moist heat treatment on ruminal and intestinal disappearance of amino acids from rapeseed meal. Journal of Dairy Science 78: 1552-1560. https://doi.org/10.3168/jds.S0022-0302(95)76777-7

Oldham, J.D. 1984. Protein energy relationships in dairy cows. Journal of Dairy Science 67: 1090-1114. https://doi.org/10.3168/ jds.S0022-0302(84)81410-1

Petit, H.V., Rioux, R. \& Ouellet, D.R. 1997. Milk production and intake of lactating cows fed raw or extruded peas. Journal of Dairy Science 80: 3377-3385. https://doi.org/10.3168/jds.S0022-0302(97)76313-6

Pires, A.V., Eastridge, M.L. \& Firkins, J.L. 1996. Roasted soybeans, blood meal, and tallow as sources of fat and ruminally undegradable protein in the diet of lactating cows. Journal of Dairy Science 79: 1603-1610. https://doi.org/10.3168/jds.S00220302(96)76523-2

Puhakka, L., Jaakkola, S., Simpura, I., Kokkonen, T. \& Vanhatalo, A. 2016. Effects of replacing rapeseed meal with faba bean at 2 concentrate crude protein levels on feed intake, nutrient digestion, and milk production in cows fed grass silage-based diets. Journal of Dairy Science 99: 7993-8006. https://doi.org/10.3168/jds.2016-10925

Ramin, M. \& Huhtanen, P. 2013. Development of equations for predicting methane emissions from ruminants. Journal of Dairy Science 96: 2476-2493. https://doi.org/10.3168/jds.2012-6095

Schingoethe, D.J., Casper, D.P., Yang, C., Illg, D.J., Sommerfeldt, J.L \& Mueller, C.R. 1988. Lactational response to soybean meal, heated soybean meal, and extruded soybeans with ruminally protected methionine. Journal of Dairy Science 71: 173-180. https://doi.org/10.3168/jds.S0022-0302(88)79539-9

Sjaunja, L. O., Baevre, L., Junkkarinen, L., Pedersen, J. \& Setälä, J. 1990. A nordic proposal for an energy corrected milk (ECM) formula. In: Gallion P. \& Chabert, Y. (eds). Committee of Recording and Productivity of Milk Animals. Proceedings of 27th Session Int. the Netherlands. Wageningen: EEAP publication. p. 156-157.

Spörndly, R. 2003. Fodertabeller för idisslare Report no. 257. The Swedish University of Agricultural Science, Uppsala, Sweden.

Tuominen, P., Tverås, B., Strudsholm, F. \& Andresen, N. 2016. Organic milk production in Finland, Norway, Denmark and Sweden. www.jordbruksverket.se/download/18.../Organic_milk_nordic_countries_report.pdf

Tuori, M., Kaustell, K., Valaja, J., Aimonen, E., Saarisalo, E. \& Huhtanen, P. 1996. Rehutaulukot ja ruokintasuositukset: märehtijät - siat - siipikarja - turkiseläimet - hevoset (Feed tables and feeding recommendations). 2nd Edition. Helsingin yliopisto. 99 p.

Vaga, M., Hetta, M. \& Huhtanen, P. 2017. Effects of heat treatment on protein feeds evaluated in vitro by the method of estimating utilisable crude protein at the duodenum. Journal of Animal Physiology and Animal Nutrition. https://doi.org/10.1111/jpn.12646

Vanhatalo, A., Ahvenjärvi, S. \& Jaakkola, S. 2004. Metabolic and production responses in dairy cows fed peas or rapeseed meal on grass silage based diets. Journal of Animal Feed Science and Technology 13: 231-234. https://doi.org/10.22358/jafs/73847/2004 